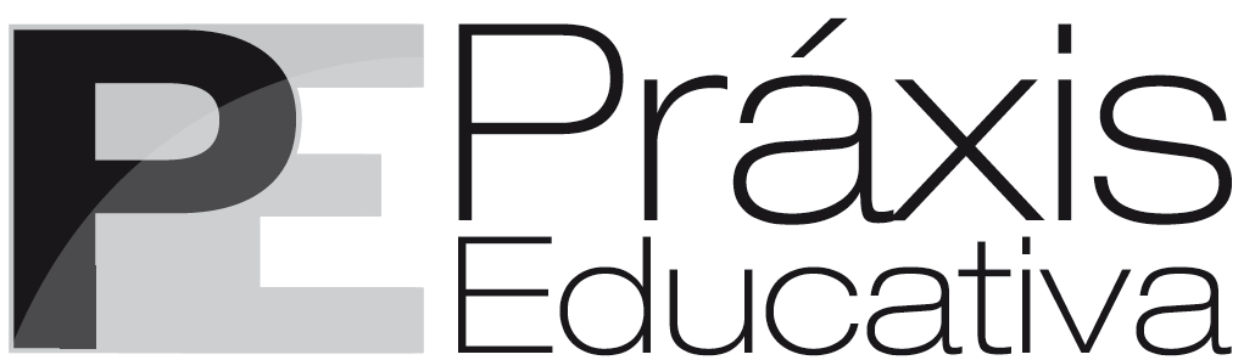

ISSN 1809-4309 (Versão online) DOI: 10.5212/PraxEduc.v.12i3.010

\title{
A disciplina Libras na formação de professores: desafios para a formulação de espaços educacionais bilíngues
}

\section{Libras's discipline on teacher training: challenges for the creation of bilingual educational spaces}

\section{La asignatura Libras en la formación de profesores: desafíos para la formulación de espacios educacionales bilingües}

\author{
Juliana Cavalcante de Andrade Louzada* \\ Sandra Eli Sartoreto de Oliveira Martins** \\ Claudia Regina Mosca Giroto ${ }^{* * *}$
}

Resumo: No campo de estudo selecionado, interessa investigar se a oferta da disciplina Libras constituise num espaço formativo orientado para a consolidação de práticas educacionais bilíngue, em consonância com o Decreto Federal n ${ }^{\circ}$ 5.626/05. A análise dos documentos disponíveis online permitiu a identificação de 19 cursos que ofertavam disciplinas em atendimento às políticas de educação bilíngue para surdos. Da amostra de cursos investigados, foram encontradas 22 disciplinas. Apoiada na Análise de Conteúdo, os dados obtidos nos planos de ensino foram organizados e analisados em três categorias: a) Ensino de Libras; b) Conteúdo sobre a Libras e c) Políticas Públicas e fundamentos da educação de surdos. Os resultados evidenciaram que a disciplina Libras tem se configurado como possibilidade de difusão e ensino desta modalidade de linguagem. Conclui-se, portanto que a sua oferta contribuiu para desfazer equívocos sobre a escolarização dos surdos, na perspectiva bilíngue.

Palavras-chave: Formação de Professores. Língua Brasileira de Sinais. Política Educacional Bilíngue.

Abstract: In the selected field of study, it's important to investigate whether the Libras discipline offer constitutes a formative and oriented space to bilingual educational consolidation according to Decree $\mathrm{n}^{\circ}$ 5.626/05. The analysis of online available documents allowed to identify 19 courses that offered disciplines about bilingual education policies for the deaf. Among these courses 22 disciplines was found. Supported by content analysis, the data were organized in three categories: a) Libras teaching; b) Content

\footnotetext{
* Mestranda do Programa de Pós-Graduação em Educação da FFC/UNESP/Campus de Marília. Grupo de Estudos e Pesquisas em Deficiência e Inclusão - GEPDI. E-mail: <ju_louzada@hotmail.com>.

** Professora do Departamento de Educação Especial e do Programa de Pós-Graduação em Educação da FFC/UNESP/Campus de Marília. Grupo de Estudos e Pesquisas em Deficiência e Inclusão - GEPDI. E-mail: $<$ sandreli@unesp.marilia.br>.

*** Professora do Departamento de Educação Especial e do Programa de Pós-Graduação em Educação da FFC/UNESP/Campus de Marília. Docente do Programa de Pós-Graduação em Educação Escolar/FCLAr/UNESP/Campus de Araraquara. Grupo de Estudos e Pesquisas em Atividade e Desenvolvimento Infantil-GEPADI. E-mail: <claudia.mosca@marilia.unesp.br>.
} 
about Libras; and c) Public Policies and Fundamentals of deaf education. Results shown that Libras discipline has been configured as a possibility of diffusion and teaching of this language modality, in the mentioned courses. Overall that the offer will contributes to fade away the misunderstanding of deaf schooling in the bilingual perspective.

Keywords: Teacher training courses. Brazilian Sign Language. bilingual education policies.

Resumen: En El campo de estudios seleccionado, interesa investigar si la oferta de la asignatura de Libras se constituye espacio formativo orientado para la consolidación de prácticas educacionales bilingües, en consonancia con el Decreto $\mathrm{n}^{\circ}$ 5.626/05. El análisis de los documentos disponibles online permitió la identificación de 19 cursos que ofertaban asignaturas en atendimiento a las políticas de educación bilingüe para los sordos. De la amuestra de cursos investigados, fueron encontradas 22 asignaturas. Apoyado en el análisis de contenido, los datos obtenidos en los planes de enseñanza fueron organizados en tres categorías: a) Enseñanza de Libras; b) Contenido sobre la Libras y c) Políticas Públicas y fundamentos de la educación de sordos. Los resultados evidenciaron que la asignatura Libras se ha configurado como posibilidad de difusión y enseñanza de esta modalidad de lenguaje, en los cursos mencionados. Por sobre todo, se alerta para que el ofrecimiento contribuya para deshacer equívocos sobre la escolarización de los sordos, en la perspectiva bilingüe.

Palabras-clave: Formación de docentes. Lengua Brasileña de Señales. Política de Educación Bilingüe.

\section{Educação Inclusiva: que caminhos percorrem estudantes surdos?}

Constituir sistemas de ensino que atendam aos princípios da educação inclusiva tem sido o grande desafio da atualidade para diferentes profissionais ligados à área da educação, pois tal perspectiva exigirá uma visão mais global sobre o atendimento às necessidades educacionais especiais do público da educação especial, dentre os quais, situam-se os estudantes com deficiência, transtorno global do desenvolvimento (TGD), altas habilidades e superdotação ${ }^{1}$ (BRASIL, 2008, 2015).

Assumir tais princípios significa garantir condições educacionais para que todos os estudantes tenham acesso ao currículo escolar de forma que possam alcançar níveis mais elevados de escolarização. Concebida como uma modalidade transversal de apoio ao ensino, a educação especial caracteriza-se pela oferta do serviço de apoio pedagógico especializado desde a educação infantil até a educação superior. Nesta escola, é desejável que a participação da família e da comunidade escolar atue na busca por condições mais acessíveis aos meios de transportes, nos mobiliários, nas comunicações e informação; e articulação intersetorial na implementação das políticas públicas.

A escola inclusiva preconiza a convivência das diversidades, pressupondo que as diferenças são constituintes do ser humano e caracterizam-se como a maior riqueza da vida em sociedade. Para que a educação inclusiva se constitua como uma política afirmativa em diferentes etapas de ensino, os atores deste processo deverão ser capazes de responder às necessidades especiais do público nela presente, na medida em que [...] "incluir significa organizar e implementar respostas educativas que facultem a apropriação do saber, do saber fazer e da capacidade crítica e reflexiva; envolve a remoção de barreiras arquitetônicas sim, mas sobretudo das barreiras atitudinais - aquelas referentes ao "olhar" das pessoas normais e desinformadas -

\footnotetext{
1 Cumpre esclarecer que o termo Transtornos Globais do Desenvolvimento (TGD) é referenciado na Política Nacional de Educação Especial na perspectiva da Educação Inclusiva - PNEEPEI (BRASIL, 2008), porém não é citado na Lei Brasileira de Inclusão (BRASIL, 2015), na medida em que o termo foi amplamente debatido e, sendo substituído pelo emprego do termo Transtorno do Espectro Autista (TEA), denominado, recentemente, como pertencente ao espectro da deficiência, conforme lei no 12.764/2012 (BRASIL, 2012).
}

Práxis Educativa, Ponta Grossa, v. 12, n. 3, p. 864-886, set./dez. 2017 Disponível em: <http://www.revistas2.uepg.br/index.php/praxiseducativa> 
A disciplina Libras na formação de professores: desafios para a formulação de espaços educacionais...

para que se promova a adequação do espaço psicológico que será compartilhado por pessoas muito diferentes entre si” (CARVALHO, 1999 apud FERREIRA, 2007, p. 44).

Adotar esses princípios exigirá, necessariamente, reconhecer as demandas educacionais especiais de estudantes com deficiência, assegurando o acesso, a circulação e a sua permanência em espaços comuns da escola. Sabe-se que a política gerada representa uma importante conquista na atualidade, no entanto, considerar que esse avanço promove mudanças pontuais nos direitos deste grupo, não valida uma mudança de concepção de atitude diante da pessoa com deficiência. Por conseguinte, entende-se que não basta estar presencialmente nas salas e/ou nos espaços regulares de ensino, há que se avaliar porque ainda - em grande parcela, este grupo não consegue usufruir do capital cultural que circula nas instituições, nas diferentes etapas de educação.

Isso posto, discorrer sobre a formação docente para atuar na perspectiva da educação inclusiva, parece ser um tema importante e pertinente para o contexto atual. Neste processo, interessará especialmente ponderar, neste artigo, as contribuições das políticas públicas de formação docente para o reconhecimento e valorização da educação bilíngue, almejada pelos estudantes surdos, usuários da Língua Brasileira de Sinais - Libras.

A partir dos trabalhos que questionam a Política Nacional de Educação Especial na perspectiva da Educação Inclusiva - PNEEPEI (BRASIL, 2008), que foi reiterada recentemente pela Lei Brasileira de Inclusão - LBI (BRASIL, 2015), assim como diferentes autores da área da surdez (LODI, 2013, 2014; FERNANDES, 2011; FERNANDES; MOREIRA, 2014; GIROTO; MARTINS; LIMA, 2015) passamos a suspeitar que a escola regular (na atualidade) seja o espaço prioritário para a escolarização dos surdos. Diferente das políticas vigentes, que sugerem a inserção do alunado surdo em classes regulares de ensino, o texto em questão assumirá que a oferta de escolarização para estes alunos ocorra em escolas ou classes de instrução de Língua de Sinais - com professores bilíngues, na educação infantil e até o final das séries iniciais do Ensino Fundamental. Somente após a conclusão do primeiro ciclo do ensino fundamental, é que a presença do profissional Tradutor/Interprete de Libras (TILS) passa a ser desejável, no processo educacional.

Tal medida tem sido referenciada por resguardar o direito dos surdos em estudar em ambientes educacionais bilíngues nos quais a Libras é reconhecida como língua de instrução (L1) e de apropriação ao currículo escolar para os surdos, sendo o português escrito, (L2) considerado a segunda língua (BRASIL, 2005). Nesta perspectiva, entende-se que a linguagem é a base para o desenvolvimento de todas as funções mentais superiores, desenvolvendo-se nas relações sociais com outros que a tenham como característica comum, ou seja, que se utilizem da mesma língua. A apropriação desta língua pelos surdos permitirá que estabeleçam relações significativas com os outros e se constituam como sujeitos por meio da linguagem.

Apoiada nos estudos de Bakhtin [Volochínov] (2014, p. 127), ao tomar a linguagem como uma prática social que tem na língua a sua realidade material, afastamo-nos de compreendê-la como um sistema abstrato de formas linguísticas à parte da atividade do falante, mas sim como um processo de evolução ininterrupto, constituído nas relações sociais da interação verbal, realizada na enunciação. Caracterizada como fenômeno ideológico por excelência, a palavra passa a ser compreendida como responsável por aportar uma carga de valores culturais que expressam as divergências de opiniões e as contradições da sociedade, mediadas pelo uso da linguagem numa arena de conflitos.

Isso posto, discorrer sobre o diálogo em língua de sinais, frente aos constructos da teoria enunciativa, implicará assumir que esta se constituirá na relação, nas trocas do cotidiano/social com os outros indivíduos igualmente dotados da capacidade e experiência de uso da linguagem

Práxis Educativa, Ponta Grossa, v. 12, n. 3, p. 864-886, set./dez. 2017 Disponível em: < http://www.revistas2.uepg.br/index.php/praxiseducativa > 
em sua materialidade discursiva - em Libras. Esta condição evoluirá sob o efeito da interação contínua e permanente com os enunciados individuais do outro (ouvintes ou não; falantes e/ou sinalizadores) que por serem dotados da capacidade de enunciar se constituirão como sujeitos no/pelo dialogismo (BAKHTIN/ VOLOCHÍNOV, 2014).

Posto isso, Fernandes (2011) e Fernandes e Moreira (2014) comungam da ideia de que a consolidação da educação bilíngue passará pela necessidade de aceitá-los [os surdos] como pertencentes a um grupo linguístico minoritário, cuja identificação cultural se dá com a Língua Brasileira de Sinais (Libras), devendo esse debate, portanto, ocupar a centralidade das formas nos processos e espaços educacionais. Nele, a Libras é identificada, simbolicamente, por signos visuais e não orais-auditivos, como na grande maioria das línguas naturais e, por isso, exigirá de quem a utiliza a constituição diferenciada de sentidos sobre o mundo, com impactos culturais que assemelham os surdos, na luta pelo reconhecimento político de sua diferença linguística, a outros grupos étnicos e minoritários (FERNANDES, 2011). Portanto, comportamento linguístico diferenciado daqueles que têm como Língua materna (a Libras) uma língua diferente daquela falada pela sociedade majoritária (o português). Adotar essa premissa implicará, para autora, aceitar que a educação dos surdos se insere num território de disputas, no qual a Libras e a língua portuguesa estão em tensão constante nas interações verbais e são marcadas por relações de poder explicitamente assimétricas no espaço escolar, onde o aprendizado da língua portuguesa como L2 tem provocado a marginalização desses estudantes (FERNANDES, 2009).

Tal medida converge com os dispositivos descritos no Relatório sobre a Política Linguística da Educação Bilíngue - Língua Brasileira de Sinais e Língua Portuguesa, publicado em 2014 pelo Ministério da Educação - Secretaria de Educação Continuada, Alfabetização, Diversidade e Inclusão (MEC/SECADI), o Grupo de Trabalho (GT), designado pelas Portarias $\mathrm{n}^{\circ} 1.060 / 2013$ e $\mathrm{n}^{\circ}$ 91/2013, do MEC/SECADI, promoveu reflexões essenciais para subsidiar a implementação da educação bilíngue - Libras e Língua Portuguesa, no Brasil (BRASIL, 2014) que define a Educação Bilíngue, como:

A Educação Bilíngue de surdos envolve a criação de ambientes linguísticos para a aquisição da Libras como primeira língua (L1) por crianças surdas, no tempo de desenvolvimento linguístico esperado e similar ao das crianças ouvintes, e a aquisição do português como segunda língua (L2). A Educação Bilíngue é regular, em Libras, integra as línguas envolvidas em seu currículo e não faz parte do atendimento educacional especializado. O objetivo é garantir a aquisição e a aprendizagem das línguas envolvidas como condição necessária à educação do surdo, construindo sua identidade linguística e cultural em Libras e concluir a educação básica em situação de igualdade com as crianças ouvintes e falantes do português (BRASIL, 2014, p. 6).

A despeito dos avanços políticos, sobretudo legislativos, conforme apontados pela situação de bilinguismo dos surdos brasileiros, como lembram Fernandes e Moreira (2014) e Lodi (2013), ainda prevalece a manutenção de uma concepção social na qual esses estudantes são não apenas narrados como deficientes da linguagem, mas relegados, de fato, a essa situação, ao não estarem dadas as condições materiais de sua produção histórica como cidadãos bilíngues, desde o seio familiar até círculos sociais mais amplos, como é o caso da escola e do trabalho. É histórica a invisibilidade das pessoas surdas e de sua língua de sinais no contexto das políticas e programas de bilinguismo nacional, considerando que a oficialização da língua Brasileira de Sinais acontece apenas em 2002 (há pouco mais de uma década) e sua regulamentação pelo Decreto Federal no 5.626/2005 (BRASIL, 2005). O principal desdobramento da invisibilidade social provocada, por longo tempo, pela imposição da língua portuguesa (falada) eleita (e imposta aos surdos) como

Práxis Educativa, Ponta Grossa, v. 12, n. 3, p. 864-886, set./dez. 2017 Disponível em: <http://www.revistas2.uepg.br/index.php/praxiseducativa> 
A disciplina Libras na formação de professores: desafios para a formulação de espaços educacionais...

único meio possível para promover a escolarização de crianças e jovens surdos no sistema de ensino brasileiro (FERNANDES, 2009, 2011).

Assim, os defensores da educação bilíngue para surdos consideram que a sua implementação, no contexto atual, tem sido um processo lento, pois ao passo que demanda o envolvimento e compromisso de todos os atores da escola, com destaque a participação de professores e alunos surdos. Para a oferta de propostas educacionais bilíngues, a escola deve contar com presença de professores surdos, formados e qualificados para o exercício da função, além de considerar, em seu projeto político pedagógico, discussões que considerem, na inserção de conteúdos curriculares, as diferenças linguísticas, pedagógicas e cognitivas do seu alunado, como constitutiva do seu processo formativo. Aliados a estas ponderações, acrescenta-se a necessidade de construir práticas pedagógicas que sejam capazes de garantir aos surdos níveis mais elevados de letramento na L2 e de apropriação dos conhecimentos veiculados no programa escolar.

A esse respeito ainda, em consonância com os achados de Leite e Martins (2012), na direção da construção de uma escola que seja inclusiva, muito há por fazer para consolidar as propostas de formação inicial de professores a fim de que sejam capazes de suplantar as transformações de organização de sistemas educacionais.

\section{A disciplina de Libras na formação de professores: dilemas atuais}

A inserção de disciplina Libras no Ensino Superior assumiu relevância após a promulgação do Decreto Federal $n^{\circ} 5.626 / 2005$ (BRASIL, 2005), que regulamentou a lei $\mathrm{n}^{\circ}$ 10.436, de 24 de abril de 2002 (BRASIL, 2002), responsável pela implementação da Libras como disciplina curricular obrigatória nos cursos de formação de professores e de fonoaudiologia.

É fato, que não se pode atribuir à oferta dessa disciplina a possibilidade de domínio da língua, dado o limite de carga horária, porém, deve-se destacar que a partir deste decreto as diferenças linguísticas e socioculturais das comunidades surdas passaram a receber alguma atenção nos cursos de formação de professores.

No entanto, Giroto, Martins e Lima (2015) denotam que a escola pouco tem se organizado para atender as singularidades linguísticas, culturais e cognitivas dos surdos no sistema regular de ensino. A esse respeito, acenam que as crianças e jovens surdos se sentem prejudicados pela baixa efetividade do sistema educacional no que se refere à garantia da aprendizagem, aliada à ineficiência da formação docente.

Acrescido a estes fatos, Fernandes (2009) refere que a língua portuguesa (falada), eleita (e imposta aos surdos) - durante o século XX, como único meio possível para promover a escolarização destes no sistema de ensino brasileiro, contribuiu para manter os surdos afastados da cultura letrada em sociedade. Ao discorrer sobre a centralidade da língua de sinais no processo de letramento, o autor lembra que seu domínio somente será apropriado pelos surdos quando esta modalidade servir de suporte cognitivo para a aprendizagem de outro sistema de signos visuais - a escrita - permitindo a apropriação da língua portuguesa como segunda língua (L2) por surdos que desconhecem o valor sonoro das palavras. Em função dessa especificidade na natureza da aquisição da segunda língua, o processo de ensino-aprendizagem da língua portuguesa por estudantes surdos vem sendo caracterizado por inúmeros pesquisadores da área como semelhante ao processo de aprendizagem de uma língua estrangeira, do ponto de vista funcional e metodológico. 
Aliados aos agravos mencionados, pode-se considerar que os professores em quem, em última análise, deposita-se a responsabilidade histórica pela inclusão de seus alunos, não falam Libras. Já os intérpretes, que têm atuado como mediadores de comunicação e apoio pedagógico nas escolas, têm uma formação deficitária e, decorrente da complexidade do processo de se tornarem proficientes em uma língua ainda marginalizada socialmente, utilizam a Língua de sinais precariamente, de forma bimodal, prejudicando apropriação do português na modalidade escrita, como possibilidade de acesso ao conhecimento escolar. Consecutivamente, na dimensão subjetiva dos fatos, o direito fundamental a Libras como língua materna, patrimônio cultural e linguístico, tem sido cerceado quando, nas experiências em escolas regulares monolíngues, os estudantes se veem limitados em suas manifestações cotidianas básicas, proibidos, pela imposição do português como língua de interação e instrução, do direito ao aprendizado e uso pleno da Libras como língua materna.

Com o intuito de verificar como se deu a implementação da disciplina Libras nas licenciaturas, Costa e Lacerda (2015) realizaram uma pesquisa bibliográfica no banco de teses da Capes e concluíram que a oferta da disciplina Libras para os cursos de formação de professores é direcionada, em sua maior parte, aos objetivos da inclusão escolar, em detrimento dos objetivos da educação bilíngue, propriamente dita. Esses autores destacam, porém, que a inserção da disciplina Libras nas licenciaturas não resolve o problema da educação de surdos no Brasil, mas possibilita maior debate acerca da inclusão escolar de alunos surdos.

A esse respeito, Giroto, Martins e Lima (2015) acrescentam que apesar da obrigatoriedade da Libras como disciplina curricular ter contribuído progressivamente para ampliar as contratações de profissionais para atuar no ensino e/ ou difusão da Libras, desde a educação infantil ao ensino superior (Pedagogia, demais licenciaturas e Fonoaudiologia), possibilitando assim uma maior visibilidade à escolarização dos surdos, advertem que as Diretrizes Curriculares Nacionais para o Curso de Pedagogia (BRASIL, 2006) deixam de ponderar aspectos importantes para a formação de pedagogos no atendimento às demandas educacionais de todos os alunos e, em particular, de surdos, usuários da Libras, em sala de aula comum.

Posto isso, referem que a inserção da Libras nos cursos de pedagogia não pode ser a única alternativa para o desenvolvimento acadêmico de surdos. Há que se pensar em propostas diferenciadas para atender as demandas educacionais desse público (GIROTO; PINHO; MARTINS, 2016), a exemplo da oferta, como defende o Instituto Nacional dos Surdos desde 2011, do curso de graduação em Pedagogia Bilíngue². Machado, Teixeira e Galasso (2017, p. 23) defendem que um curso bilíngue não se restringe a formar tradutores e/ou intérpretes de Libras para estudantes surdos, mas sua proposta pedagógica exigirá uma postura política, social para engendrar na pedagogia a partir dos "óculos surdos". Concepção esta que impacta na organização de um programa curricular que considera métodos, avaliação e gestão diferenciados, capazes de trabalhar com surdos e não-surdos, como o foco principal de uma formação amparada no princípio de educação bilíngue.

\footnotetext{
2 O Instituto Nacional de Educação de Surdos (INES), Centro de Referência Nacional na Área da Surdez, oferece Educação Básica (Educação Infantil, Ensino Fundamental e Ensino Médio) e Educação Superior - graduação e pósgraduação. A proposta de educação é bilíngue (Língua Brasileira de Sinais - Libras e Língua Portuguesa escrita) em todos os níveis - sonância com a Lei no 10.436/2002 (BRASIL, 2002) e com o Decreto no 5.626/05 (BRASIL, 2005) - e está implicada no desenvolvimento de um planejamento estratégico que envolve formação inicial e continuada de professores dentro dessa perspectiva. Em continuidade às ações que visam à consolidação e à expansão do Ensino Superior no INES e ao desenvolvimento de políticas de formação de professores, o Instituto assumiu, a convite do MEC, a responsabilidade de implementar, de acordo com o Plano Nacional dos Direitos da Pessoa com Deficiência - Plano Viver sem Limite por meio do Decreto no 7.612 (BRASIL, 2011), o curso de Pedagogia Bilíngue Licenciatura, na modalidade online (MACHADO; TEXEIRA; GALASSO, 2017).
}

Práxis Educativa, Ponta Grossa, v. 12, n. 3, p. 864-886, set./dez. 2017 Disponível em: <http://www.revistas2.uepg.br/index.php/praxiseducativa> 
A disciplina Libras na formação de professores: desafios para a formulação de espaços educacionais...

Avalizar os avanços das políticas educacionais inclusivas na escolarização dos surdos tem se constituído um desafio na atualidade. No campo de estudos selecionado, interessa investigar se a oferta da disciplina Libras constitui-se um espaço formativo orientado para a consolidação de práticas educacionais bilíngues, em consonância com o Decreto Federal no 5.626/2005 (BRASIL, 2005).

Assumir que a educação bilíngue seja uma possibilidade concreta do reconhecimento da luta dos surdos em favor das conquistas sociais, políticas e linguísticas, decorrentes da promulgação do Decreto Federal no 5.626/2005 (BRASIL, 2005), reforça a necessidade de estudos que discorram sobre a oferta desta disciplina de Libras na formação dos professores, foco deste estudo.

\section{Material e Método}

A amostra da presente pesquisa foi constituída por um total de 49 grades curriculares correspondentes aos cursos de licenciatura de três instituições de ensino superior (IES), a saber: Universidade Estadual Paulista - (UNESP); Universidade Federal de São Carlos - (UFSCar); e Universidade Federal de Santa Catarina - (UFSC). Vale mencionar que os dados aqui apresentados fazem parte de um subprojeto vinculado ao projeto em rede intitulado "Acessibilidade no Ensino Superior: da análise das políticas públicas educacionais ao desenvolvimento de mídias instrumentais sobre deficiência e inclusão" (BRASIL, 2012).

As grades curriculares foram coletadas por meio de pesquisa online nos sites dessas instituições a partir de um trabalho de busca inicialmente das matrizes curriculares e, posteriormente, dentro dessas matrizes, de disciplinas que abordavam sobre Fundamentos da Educação Inclusiva, deficiência, Libras e NEE. Tal busca ocorreu por meio do recolhimento das grades curriculares e dos planos de ensino disponíveis nos links da graduação e/ou departamentos dos cursos, disponibilizados no formato de domínio público. Os dados recolhidos das grades dos cursos foram armazenados num banco de dados, numa planilha Excel, a partir da organização das informações, a saber: unidade/universidade; local; disponibilidade da grade curricular bem como o ano de vigência da mesma; nomenclatura/nome da disciplina; carga horária/créditos da disciplina; modalidade de oferta da disciplina (obrigatória e/ou optativa); termo de busca utilizado para localizá-la; contato da coordenação do curso; identificação e oferta de disciplinas relacionadas ao tema do projeto. As informações obtidas dos planos de ensino, bem como das ementas, também seguiram organização semelhante em planilha do Excel, com os seguintes tópicos: instituição; título da disciplina; obrigatória/optativa; carga horária; objetivos; conteúdos; metodologia e ementa.

A localização das informações contidas nos documentos citados foi realizada por meio da técnica de busca por radicais, proposto por Mazo (2010), tambem utilizada nos estudos de Velden e Leite (2013). Tal proposta tem como objetivo favorecer a busca de informação agrupada por núcleo semântico e formal de uma palavra relacionada ao tema de pesquisa. Esta técnica visa a dirimir o trabalho exaustivo que envolve a busca por descritores em pesquisa bibliográfica e/ou documentária. Nas palavras das autoras

[...] o radical corresponde à raiz de uma palavra e que se mantém variável e atemporal, mesmo em função do gênero, da referência gramatical - singular e plural, por exemplo. Desta forma, o exame inicial de documentos pelo uso de radicais tem se constituído numa ferramenta de pesquisa viável que permite a análise prévia da classificação rápida do material que será objeto do estudo do

Práxis Educativa, Ponta Grossa, v. 12, n. 3, p. 864-886, set./dez. 2017 Disponível em: <http://www.revistas2.uepg.br/index.php/praxiseducativa> 
pesquisador, podendo abranger diversos enunciados correspondentes a um mesmo tema ou tópico [...] (VELDEN; LEITE, 2013, p. 501).

A partir dos estudos de Velden e Leite (2013), foram utilizados para localizar as disciplinas nas grades curriculares os descritores relacionados à Libras. Esta descrição tem por objetivo identificar e quantificar as disciplinas que atendem aos objetivos desta pesquisa. Dada a localização das disciplinas, foram recolhidos os planos de ensino disponíveis em meio eletrônico e, para aquelas disciplinas em que o plano não estava disponível online, o mesmo foi solicitado ao coordenador do curso por meio de ofício, via e-mail.

Vale mencionar que a maioria dos planos de ensino obtidos encontravam-se organizados no mesmo formato, provavelmente em razão da sistematização de um mesmo formulário de plano de ensino para todos os cursos e uma padronização utilizada pelas IES estudadas, semelhantemente ao ocorrido no estudo de Giroto, Martins e Lima (2015), ao investigarem a inserção da disciplina Libras em cursos de pedagogia de uma universidade pública estadual.

De posse desses planos com tais informações, procedeu-se à análise de conteúdo dos mesmos, conforme proposta por Bardin (2011), que tem como ponto de partida a mensagem, seja ela verbal (oral ou escrita), gestual, documental, silenciosa, figurativa ou diretamente provocada.

Para tal, foram consideradas as seguintes informações: nome da disciplina; modalidade da disciplina (obrigatória, optativa ou estágio); créditos; carga horária; ementa; objetivos; proposta da disciplina; metodologia de ensino; métodos de avaliação; referencial bibliográfico; nome do docente responsável pela disciplina; e departamento ao qual a disciplina pertencia. Nos momentos de consulta realizada, pode-se perceber que foram raros os casos da ausência de especificação da metodologia utilizada e/ou da modalidade da disciplina (obrigatória/optativa). Tais informações foram sistematizadas numa planilha Excel que contemplava os seguintes tópicos: instituição; nome da disciplina; modalidade de oferta; carga horária; objetivos; conteúdos; metodologia e ementa.

Segundo Lüdke e André (1986), a análise documental é caracterizada como importante técnica na pesquisa qualitativa, pois pode completar informações obtidas de outras técnicas e revelar aspectos novos de um problema.

A técnica de análise de conteúdo permitiu analisar os conteúdos recolhidos no estudo a partir da análise temática, visando a atender aos objetivos propostos. Inicialmente foi realizada a categorização, uma operação de classificação dos elementos que constituem o conjunto de dados, por diferenciação e, seguidamente, por um reagrupamento, sendo tal categorização a passagem dos dados brutos a dados organizados (BARDIN, 2011).

Rocha e Deusdará (2005) destacam, sobre a análise de conteúdo, o

rigor do método como forma de não se perder na heterogeneidade de seu objeto. Nascida de uma longa tradição de abordagem de textos, essa prática interpretativa se destaca, a partir do início do século XX, pela preocupação com recursos metodológicos que validem suas descobertas. $\mathrm{Na}$ verdade, trata-se da sistematização, da tentativa de conferir maior objetividade a uma atitude que conta com exemplos dispersos, mas variados, de pesquisa com textos (ROCHA; DEUSDARÁ, 2005, p. 308).

Desse modo, as informações recolhidas nos planos de ensino obtidos foram agrupadas e, com base nos estudos de Giroto, Martins e Lima (2015) acerca da inserção da disciplina Libras 
A disciplina Libras na formação de professores: desafios para a formulação de espaços educacionais...

em cursos de Pedagogia, foram confirmadas três tendências temáticas de organização. Essas tendências foram determinadas como categorias de análise, a saber:

a) Ensino de Libras: apontou aspectos voltados para situações de apropriação e/ou ensino da língua, ainda que de forma instrumental, difusão da língua e práticas de comunicação desta língua nas disciplinas;

b) Conteúdos sobre a Libras: abordou reflexões sobre o resgate histórico da Libras e a cultura surda;

c) Políticas públicas e fundamentos da educaşão dos surdos: relacionada ao papel do educador nos processos de ensino e aprendizagem, no desenvolvimento de práticas educativas e no uso de tecnologias de informação e comunicação aplicadas no contexto das políticas educacionais e linguísticas para a educação dos surdos.

Além dessas categorias, a análise dos dados possibilitou a identificação de subcategorias, considerando a análise, nos materiais recolhidos da ementa, do objetivo e do conteúdo.

Essas subcategorias encontram-se explicitadas nos quadros 1, 2 e 3, apresentados a seguir, de forma a sistematizar as informações acerca das tendências, identificação e descrição, seguidas de exemplos de trechos recortados dos planos de ensino obtidos, com vistas a facilitar a compreensão acerca das formas de análise dos dados obtidos:

Quadro 1 - Apresentação das subcategorias e seus respectivos exemplos de recortes do plano de ensino para a categoria "Ensino de Libras"

\begin{tabular}{|l|l|l|}
\hline Subcategoria & Descrição & Exemplo \\
\hline Práticas discursivas em & $\begin{array}{l}\text { Diferentes abordagens das } \\
\text { práticas discursivas da Libras }\end{array}$ & $\begin{array}{l}\text { "Aquisição de repertório lexical em Libras para } \\
\text { o ensino de Educação Física; Estratégias de } \\
\text { reprodução e aquisição de novos sinais". } \\
\text { (Trecho retirado do conteúdo do plano } \\
\text { de ensino da disciplina Introdução ao } \\
\text { Estudo da Língua Brasileira de Sinais do } \\
\text { curso de Ed. Física - UNESP/Bauru). } \\
\text { "Iniciar uma conversação através da lingua de } \\
\text { sinais com pessoas surdas." (Trecho retirado } \\
\text { da ementa do plano de ensino da } \\
\text { disciplina Libras I do curso de Geografia } \\
\text { - UFSC). } \\
\text { "Ensino prático da Libras" (Trecho retirado } \\
\text { da ementa do plano de ensino da } \\
\text { disciplina Introdução à Libras - Libras I } \\
\text { do curso de Física - UFSCar/São } \\
\text { Carlos). }\end{array}$ \\
\hline
\end{tabular}

Fonte: Elaborado pelas autoras. 
Quadro 2 - Apresentação das subcategorias e seus respectivos exemplos de recortes do plano de ensino para a categoria "Conteúdos sobre a Libras"

\begin{tabular}{|c|c|c|}
\hline Subcategoria & Descrição & Exemplo \\
\hline $\begin{array}{l}\text { História da Libras na } \\
\text { sociedade }\end{array}$ & $\begin{array}{l}\text { Discorre sobre o contexto } \\
\text { histórico da Libras na sociedade }\end{array}$ & $\begin{array}{l}\text { "Introdução à história da Lingua Brasileira de } \\
\text { Sinais" (Trecho retirado do conteúdo do } \\
\text { plano de ensino da disciplina Introdução } \\
\text { ao Estudo da Língua Brasileira de Sinais } \\
\text { do curso de Ed. Física - UNESP/Bauru). } \\
\text { "Desvendar a bistória da lingua de sinais } \\
\text { brasileira enquanto elemento constituidor do } \\
\text { sujeito surdo". (Trecho retirado da ementa } \\
\text { do plano de ensino da disciplina Libras I } \\
\text { do curso de Geografia - UFSC). } \\
\text { "Demonstrar sobre os fundamentos da educação } \\
\text { dos surdos no mundo e no Brasil" (Trecho } \\
\text { retirado do objetivo do plano de ensino } \\
\text { da disciplina Introdução à Libras - Libras } \\
\text { I do curso de Matemática - } \\
\text { UFSCar/Sorocaba). }\end{array}$ \\
\hline $\begin{array}{l}\text { Aspectos linguísticos } \\
\text { da Libras }\end{array}$ & $\begin{array}{l}\text { Aspectos teóricos/gramaticais } \\
\text { envolvendo o estudo sobre a } \\
\text { Libras }\end{array}$ & $\begin{array}{l}\text { "Base linguistica e lexical em Lingua Brasileira } \\
\text { de Sinais" (Trecho retirado do conteúdo } \\
\text { do plano de ensino da disciplina } \\
\text { Introdução a Ensino de Libras do curso } \\
\text { de Matemática - UNESP/Bauru). } \\
\text { "Conbecer aspectos básicos da estrutura da } \\
\text { lingua brasileira de sinais" (Trecho retirado } \\
\text { do objetivo do plano de ensino da } \\
\text { disciplina Língua Brasileira de Sinais do } \\
\text { curso de Ciências Biológicas - UFSC). } \\
\text { "Desenvolver um conhecimento básico da Lingua } \\
\text { Brasileira de Sinais (Libras)" (Trecho } \\
\text { retirado do objetivo do plano de ensino } \\
\text { da disciplina Introdução à Libras - Libras } \\
\text { I do curso de Física - UFSCar/São } \\
\text { Carlos). }\end{array}$ \\
\hline $\begin{array}{l}\text { Aspectos políticos, } \\
\text { Culturais } \\
\text { identitários da pessoa } \\
\text { surda }\end{array}$ & $\begin{array}{l}\text { Destaca aspectos relacionados à } \\
\text { cultura e identidade surda }\end{array}$ & $\begin{array}{l}\text { "Conbecimento da cultura e identidade surda" } \\
\text { (Trecho retirado do conteúdo do plano } \\
\text { de ensino da disciplina Introdução ao } \\
\text { Ensino da Língua Brasileira de Sinais do } \\
\text { curso de Pedagogia - UNESP/Bauru). } \\
\text { "Identidades e Culturas Surdas". (Trecho } \\
\text { retirado do conteúdo do plano de ensino } \\
\text { da disciplina Língua Brasileira de Sinais } \\
\text { do curso de Letras estrangeiras - UFSC). } \\
\text { "Noçoes sobre Cultura Surda, comunidade } \\
\text { surda e identidade surda" (Trecho retirado } \\
\text { do conteúdo do plano de ensino da } \\
\text { disciplina Libras II do curso de Filosofia } \\
\text { - UFSCar/São Carlos). }\end{array}$ \\
\hline
\end{tabular}

Fonte: Elaborado pelas autoras. 
A disciplina Libras na formação de professores: desafios para a formulação de espaços educacionais...

Quadro 3 - Apresentação das subcategorias e seus respectivos exemplos de recortes do plano de ensino para a categoria "Políticas públicas e fundamentos da educação dos surdos"

\begin{tabular}{|c|c|c|}
\hline Subcategoria & Descrição & Exemplo \\
\hline Educação Bilíngue & $\begin{array}{lrr}\text { Aborda } & \text { características } & \text { e } \\
\text { assuntos } & \text { relacionados } & \text { à } \\
\text { educação bilíngue } & \end{array}$ & $\begin{array}{l}\text { "Educação bilingue para Surdos". (Trecho } \\
\text { retirado do conteúdo do plano de ensino } \\
\text { da disciplina Introdução à Libras - Libras } \\
\text { I do curso de Matemática - } \\
\text { UFSCar/Sorocaba). }\end{array}$ \\
\hline $\begin{array}{lr}\text { Políticas rúblicas } \\
\text { educacionais } \\
\text { linguísticas }\end{array}$ & $\begin{array}{l}\text { Destaca políticas e legislações } \\
\text { relacionadas à Surdez e Libras }\end{array}$ & $\begin{array}{l}\text { "Legislação de apoio a Lingua Brasileira de } \\
\text { Sinais". (Trecho retirado do conteúdo do } \\
\text { plano de ensino da disciplina Introdução } \\
\text { ao Estudo da Língua Brasileira de Sinais } \\
\text { do curso de Ed. Física - UNESP/Bauru). } \\
\text { "Educação de Surdos e Legislação" (Trecho } \\
\text { retirado do conteúdo do plano de ensino } \\
\text { da disciplina Língua Brasileira de Sinais do } \\
\text { curso de Pedagogia - UFSC). } \\
\text { "Leis referentes à educação de alunos Surdos..." } \\
\text { (Trecho retirado do conteúdo do plano de } \\
\text { ensino da disciplina Introdução à Libras - } \\
\text { Libras I do curso de Ciencias Biológicas - } \\
\text { UFSCar/Sorocaba). }\end{array}$ \\
\hline
\end{tabular}

Fonte: Elaborado pelas autoras.

\section{Resultados e Discussão}

A análise das grades curriculares obtidas permitiu a identificação de 19 cursos que ofertavam disciplinas relacionadas à temática em questão, bem como qual das três grandes áreas do conhecimento apresentava maior oferta destas disciplinas, conforme recomenda o Decreto Federal n ${ }^{\circ}$ 5.626/2005 (BRASIL, 2005), que obriga a oferta da disciplina Libras para os cursos de pedagogia, demais licenciaturas e de fonoaudiologia. A tabela 1 apresenta a distribuição, por área de conhecimento, dos cursos que atenderam essas recomendações nas três IES estudadas.

Tabela 1 - Distribuição, por área de conhecimento, dos cursos que atendem as recomendações relacionadas à educação inclusiva nas três IES investigadas

\begin{tabular}{|c|c|c|c|c|c|c|c|c|c|}
\hline \multirow[t]{2}{*}{$\begin{array}{c}\text { Área de } \\
\text { conhecimento } \\
\text { / } \\
\text { Instituição }\end{array}$} & \multicolumn{3}{|c|}{ Quantidade de cursos } & \multicolumn{3}{|c|}{$\begin{array}{c}\text { Quantidade de cursos que } \\
\text { oferecem disciplinas } \\
\text { relacionadas à temática } \\
\text { estudada }\end{array}$} & \multicolumn{3}{|c|}{$\begin{array}{c}\text { Quantidade de cursos que } \\
\text { não oferecem nenhuma } \\
\text { disciplina relaciona à } \\
\text { temática }\end{array}$} \\
\hline & UNESP & UFSC & UFSCar & UNESP & UFSC & UFSCar & UNESP & UFSC & UFSCar \\
\hline $\begin{array}{l}\text { Ciências } \\
\text { Humanas }\end{array}$ & 27 & 15 & 6 & 1 & 4 & 3 & 26 & 11 & 3 \\
\hline $\begin{array}{l}\text { Ciências } \\
\text { Exatas }\end{array}$ & 13 & 4 & 8 & 1 & 0 & 4 & 12 & 4 & 4 \\
\hline $\begin{array}{l}\text { Ciências } \\
\text { Biológicas }\end{array}$ & 8 & 3 & 4 & 1 & 2 & 3 & 7 & 1 & 1 \\
\hline $\begin{array}{l}\text { Total/ } \\
\text { Instituição }\end{array}$ & 48 & 22 & 18 & 3 & 6 & 10 & 45 & 16 & 8 \\
\hline TOTAL & & 88 & & & 19 & & & 69 & \\
\hline
\end{tabular}

Fonte: Elaborada pelas autoras. 
De acordo com as informações da tabela 1, foi possível observar que, do total de 88 licenciaturas encontradas nas três universidades, nas diferentes áreas do conhecimento (humanas, biológicas e exatas), a UNESP ofertava, por ocasião da coleta de dados realizada, 48 cursos de licenciatura em diferentes áreas; a UFSC oferecia 22 cursos nessa modalidade; e a UFSCar, por sua vez, mantinha 18 cursos de licenciatura em funcionamento.

Os dados considerados a seguir referem-se a apenas 19 cursos do total anteriormente apresentado, visto que do total de 88 cursos considerados nas três universidades em questão, somente esses 19 ofereciam disciplinas relacionadas à temática do estudo, sendo três cursos da UNESP, seis da UFSC e dez da UFSCar.

Dentre esses 19 cursos, oito correspondiam à área de humanas, seis à área de biológicas e cinco à área de exatas, totalizando uma oferta de 22 disciplinas. O Gráfico 1 representa a quantidade de cursos que ofereciam as disciplinas, em atendimento ao Decreto Federal $\mathrm{n}^{\circ}$ 5.626/2005 (BRASIL, 2005), nas instituições investigadas.

Gráfico 1 - Distribuição dos cursos de licenciatura que oferecem ou não disciplinas em atendimento ao Decreto Federal no 5.626/2005 (BRASIL, 2005), nas IES investigadas

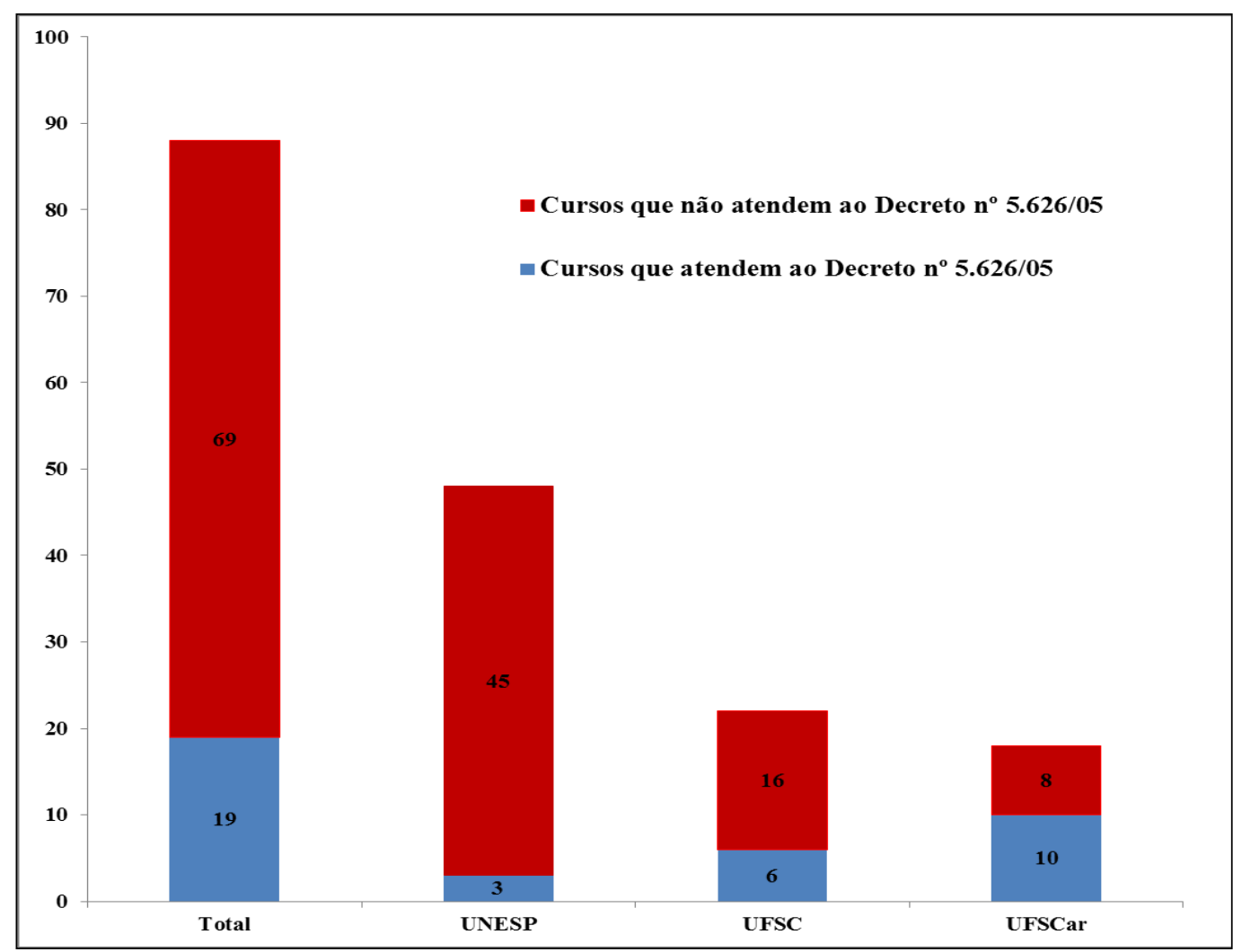

Fonte: Elaborado pelas autoras.

Como é possível observar, $21,6 \%$ dos cursos ofereciam disciplinas, em conformidade com o referido decreto. A maior parcela deles se concentrava na UFSCar, com 11,4\% dos cursos, embora as outras instituições também oferecessem cursos com disciplinas relacionadas à temática aqui investigada. Vale mencionar que a UFSCar tem tradição na formação de professores em Educação Especial e mantém em funcionamento um curso de licenciatura em Educação Especial.

Por meio desse levantamento, constata-se que, apesar de essas universidades terem envidados esforços, nos últimos anos, para atender às especificações contidas nesse decreto, no 
A disciplina Libras na formação de professores: desafios para a formulação de espaços educacionais...

que diz respeito à inserção da disciplina Libras de forma obrigatória, nos cursos de pedagogia, demais licenciaturas e de fonoaudiologia, estão longe de concretizar o prazo estabelecido nesse documento, desde sua promulgação em 2005, para tal inserção: “[...] I - até três anos, em vinte por cento dos cursos da instituição; II - até cinco anos, em sessenta por cento dos cursos da instituição; III - até sete anos, em oitenta por cento dos cursos da instituição; e IV - dez anos, em cem por cento dos cursos da instituição" (BRASIL, 2005, p. 3). Ressalta-se, ainda, a recomendação contida nesse mesmo documento acerca da inserção da Libras, de forma optativa, nos demais cursos de graduação das IES, meta que, certamente, está longe de se materializar, se for levada em consideração a morosidade com que a implantação obrigatória da disciplina de Libras nos cursos de pedagogia, demais licenciaturas e de fonoaudiologia tem sido conduzida.

A esse respeito, Giroto, Martins e Lima (2015, p. 745) pontuam que “[...] após 10 anos de publicação do referido documento, seria esperado que 100\% dos cursos de formação de professores [...], assim como de Fonoaudiologia [...], tivessem incluído a disciplina Libras em suas grades curriculares".

No âmbito da oferta desta disciplina nas IES estaduais do Estado de São Paulo, tem-se o conhecimento de que foi reconhecida como componente curricular em cursos e programas de formação de professores da Educação Básica, recentemente, por meio da Deliberação CEE/SP $\mathrm{n}^{\mathrm{o}} 111 / 2012$ e suas alterações, que regem esta matéria e dão outras providências sobre as diretrizes curriculares nacionais para os cursos de formação inicial de professores. Embora as orientações sobre o seu reconhecimento tenham ocorrido no âmbito nacional há mais de uma década (BRASIL, 2005), parte dos pressupostos sobre a sua obrigatoriedade nos cursos de licenciatura parecem apoiar-se na Política Nacional de Educação Especial na Perspectiva da Educação Inclusiva - PNEEPEI (BRASIL, 2008), que defende a inserção de conteúdos que permitam ao professor identificar o que se tem discutido e priorizando no ambiente escolar e no processo de ensino e aprendizagem do público-alvo da educação especial, dentre os quais, destacam-se os alunos com surdez.

De acordo com Vitaliano et al. (2012), tal situação é também corroborada pelo fato de as Diretrizes Curriculares Nacionais para o Curso de Pedagogia (BRASIL, 2006), apesar de mencionarem a atuação de professores frente às demandas educacionais da diversidade de alunos presente nos diferentes contextos educacionais, não problematizarem aspectos teóricooperacionais importantes para escolarização desses alunos, a exemplo do surdo usuário da Libras.

Ao discorrer sobre esse tema de estudos, Giroto, Martins e Lima (2015) alertam para a necessidade de discussão mais aprofundada sobre o papel dessa disciplina na formação de professores.

Em um texto mais recente, Giroto, Pinho e Martins (2016) discorrem sobre a importância de se considerar o perfil e qualificação dos profissionais que têm ministrado essas disciplinas para a formação dos professores e que são, portanto, responsáveis pela educação dos surdos matriculados em sala de aula comum, no ensino regular. Ressaltam neste trabalho a necessidade de as IES constituírem, em seu quadro funcional, professores capacitados para o uso e difusão da Libras, com vistas à oferta da educação bilíngue desses alunos. Dito de outro modo, referem que

[...] as propostas de formação docente devem contemplar reflexões sobre as metodologias de ensino apropriadas às demandas educacionais dos surdos, na apropriação da Língua Portuguesa, a partir do acompanhamento de metodologia de ensino de segunda língua. Desconsiderar tal prerrogativa como conteúdo na formação docente parece colaborar para manter as condições insatisfatórias dos mesmos, na apropriação dessa modalidade linguística. A

Práxis Educativa, Ponta Grossa, v. 12, n. 3, p. 864-886, set./dez. 2017 Disponível em: < http://www.revistas2.uepg.br/index.php/praxiseducativa > 
complexidade dos temas que cercam a educação dos surdos deve constituir o foco da organização de propostas de formação continuada da equipe escolar. Assim, o reconhecimento das diferenças linguísticas dos surdos precisa orientar a compreensão, por parte dos profissionais envolvidos, acerca dos conteúdos curriculares abordados e, posteriormente, avaliados em sua primeira língua, a Libras (GIROTO; PINHO; MARTINS, 2016, p. 164).

Igualmente, a inserção desta disciplina na formação docente, representa uma conquista recente dos movimentos da militância da área da surdez em favor do reconhecimento desta língua no desenvolvimento cognitivo, linguístico e educacional dos surdos. Destarte, para além da discussão da sua oferta como componente curricular obrigatório, os cursos de licenciaturas analisados parecem reafirmar o compromisso frente às políticas que defendem a educação bilíngue para surdos, visando à acessibilidade do educando surdo no ambiente escolar e no processo de ensino e aprendizagem - em classes bilíngues e/ou escola para surdos, contrariando a PNEEPEI (BRASIL, 2008), conforme já apontado por diferentes pesquisadores (LODI, 2014; FERNANDES; MOREIRA, 2014; GIROTO; MARTINS; LIMA, 2015). A ausência de políticas institucionais apropriadas que problematizem a sua regulamentação nas IES investigadas parece contribuir para que aspectos da consolidação de espaços educacionais bilíngues aos surdos, na educação básica (educação infantil e séries iniciais do ensino fundamental), sejam negligenciados pelos atores desse processo, conforme proposto pelo Decreto Federal no 5.626/2005 (BRASIL, 2005).

No tocante à análise dos conteúdos dos planos de ensino, foi possível observar a forma como se deu a distribuição das categorias, a partir das informações disponibilizadas, conforme demonstrado nos quadros 4,5 e $6 .^{3}$

Quadro 4 - Recorrência das subcategorias nos planos de ensino da categoria "Ensino de Libras"

\begin{tabular}{|c|c|c|c|c|c|}
\hline \multirow{2}{*}{$\begin{array}{c}\text { Instituição/Local } \\
\text { - Curso }\end{array}$} & \multirow{2}{*}{ Título/disciplina } & \multirow{2}{*}{ Subcategoria } & \multicolumn{3}{|c|}{ Recorrência } \\
\hline & & & Objetivo & Conteúdo & Ementa \\
\hline 3.Ufs. - Física & \multirow{5}{*}{ Intr. à Libras - Libras I } & \multirow{11}{*}{$\begin{array}{l}\text { Práticas } \\
\text { Discursivas }\end{array}$} & $\mathrm{X}$ & $\bar{X}$ & $\mathrm{X}$ \\
\hline $\begin{array}{l}\text { 3.Ufs.Sor - } \\
\text { Geografia }\end{array}$ & & & X & & X \\
\hline $\begin{array}{l}\text { 3.Ufs.Sor - } \\
\text { Matemática }\end{array}$ & & & $\mathrm{X}$ & & $\mathrm{X}$ \\
\hline $\begin{array}{l}\text { 3.Ufs.Sor - } \\
\text { Ciênc. Biológicas }\end{array}$ & & & $\mathrm{X}$ & & $\mathrm{X}$ \\
\hline 3.Ufs. - Filosofia & & & $\mathrm{X}$ & $\mathrm{X}$ & $\mathrm{X}$ \\
\hline $\begin{array}{l}\text { 3.Ufs. - } \\
\text { Educação Física }\end{array}$ & $\begin{array}{l}\text { Intr. à Língua Brasileira de } \\
\text { sinais }\end{array}$ & & $\mathrm{X}$ & $\mathrm{X}$ & $\mathrm{X}$ \\
\hline $\begin{array}{l}\text { 1.UnB - } \\
\text { Matemática }\end{array}$ & Intr. ao ensino de Libras & & $\mathrm{X}$ & & $\mathrm{X}$ \\
\hline $\begin{array}{l}\text { 1.UnB - } \\
\text { Educação Física }\end{array}$ & \multirow{2}{*}{$\begin{array}{l}\text { Intr. ao estudo da língua } \\
\text { brasileira de sinais }\end{array}$} & & $\mathrm{X}$ & $\mathrm{X}$ & $\mathrm{X}$ \\
\hline $\begin{array}{l}\text { 1.UnB - } \\
\text { Pedagogia }\end{array}$ & & & $\mathrm{X}$ & $\mathrm{X}$ & $\mathrm{X}$ \\
\hline $\begin{array}{l}\text { 3.Ufs.Ar - Ciênc. } \\
\text { Biológicas }\end{array}$ & \multirow[t]{2}{*}{ Libras } & & X & $\mathrm{X}$ & X \\
\hline 3.Ufs.Sor - & & & $\mathrm{X}$ & $\mathrm{X}$ & $\mathrm{X}$ \\
\hline
\end{tabular}

${ }^{3} \mathrm{O}$ modo de organização dos quadros 4, 5 e 6 seguiu o procedimento adotado por Silva (2016). Silva, Kele Cristina. Condições de acessibilidade na universidade: o ponto de vista de estudantes com deficiência. 2016. 149f. Dissertação (Mestrado em Educação Especial) - Programa de Pós Graduação em Educação, Universidade Estadual Paulista, Marília, São Paulo, 2016. 
A disciplina Libras na formação de professores: desafios para a formulação de espaços educacionais...

\begin{tabular}{|c|c|c|c|c|}
\hline Química & & & & \\
\hline 3.Ufs.Ar - Física & & $\mathrm{X}$ & $\bar{X}$ & $\mathrm{X}$ \\
\hline $\begin{array}{l}\text { 3.Ufs.Sor - } \\
\text { Ciênc. Biológicas }\end{array}$ & & $\mathrm{X}$ & $\mathrm{X}$ & $\mathrm{X}$ \\
\hline 2.Ufs - Geografia & Libras I & & $\mathrm{X}$ & $\mathrm{X}$ \\
\hline $\begin{array}{l}\text { 3.Ufs. - } \\
\text { Pedagogia }\end{array}$ & Libras II & $\mathrm{X}$ & $\mathrm{X}$ & \\
\hline 3.Ufs. - Filosofia & & $\mathrm{X}$ & $\mathrm{X}$ & \\
\hline $\begin{array}{l}\text { 2.Ufs - Educação } \\
\text { Física }\end{array}$ & \multirow{6}{*}{ Língua Brasileira de Sinais } & $\mathrm{X}$ & & $\mathrm{X}$ \\
\hline $\begin{array}{l}\text { 2.Ufs - Letras } \\
\text { Estrangeiras }\end{array}$ & & $\mathrm{X}$ & $\mathrm{X}$ & $\mathrm{X}$ \\
\hline $\begin{array}{l}\text { 2.Ufs - Ciênc. } \\
\text { Biológicas }\end{array}$ & & $\mathrm{X}$ & $\mathrm{X}$ & $\mathrm{X}$ \\
\hline $\begin{array}{l}\text { 2.Ufs - Letras } \\
\text { Alemão }\end{array}$ & & $\mathrm{X}$ & $\mathrm{X}$ & $\mathrm{X}$ \\
\hline 2.Ufs - Francês & & $\mathrm{X}$ & $\mathrm{X}$ & $\mathrm{X}$ \\
\hline $\begin{array}{l}\text { 2.Ufs - } \\
\text { Pedagogia }\end{array}$ & & $\mathrm{X}$ & $\mathrm{X}$ & $\mathrm{X}$ \\
\hline
\end{tabular}

Fonte: Elaborado pelas autoras.

O quadro 4 apresenta a recorrência de 22 disciplinas que foram classificadas na categoria "Ensino de Libras". Nesta categoria, pode-se observar que a subcategoria Práticas Discursivas foi identificada nos objetivos de $95 \%$ dos planos de ensino considerados e em $91 \%$ das ementas, com menor recorrência nos conteúdos destes planos (77\%).

O Ensino da Libras constou como uma prática recorrente nesta subcategoria de análise. Entretanto, não foi possível avaliar como as práticas discursivas nos espaços de formação docente foram organizadas. Nesse aspecto, Giroto, Martins e Lima (2015) alertam que esta disciplina - ou seja, de ensino de Libras nesta perspectiva, pode reforçar a ideia equivocada que professor da sala de aula comum seria capaz de, a partir desta experiência e de aprendizagem nesta língua, conduzir o processo de aprendizagem do aluno surdo, em sala de aula comum, em parceria com o profissional da sala de recursos multifuncional na área da surdez e, deste modo, contemplar a oferta de educação do atendimento educacional especializado para alunos surdos, no contra turno escolar (BRASIL, 2008, 2015). Esta constatação passa ser adequada se pensada para a formação de professores das licenciaturas - Química, Física, Biologia etc. que atuarão com os alunos nas séries finais do ensino fundamental, médio e/ou superior. Antes desta fase escolar, cumpre esclarecer que a educação bilíngue para surdos deve ser organizada em conformidade com o que propõe o Decreto Federal no 5.626/2005 (BRASIL, 2005) - classe de instrução em Libras ou escola bilíngue para surdos. Modalidades que na visão principiológica da educação inclusiva prevista nos documentos internacionais (UNESCO, 1990; UNESCO, 1994), são mais inclusivas do que apenas a garantia da presença física deste aluno na sala de aula comum, sem que estejam em condições equidade de oportunidade de aprendizagem curricular.

Apesar da falta de clareza sobre o método/abordagem teórica para o ensino desta língua nos cursos de Pedagogia e demais licenciaturas, é possível supor que tal proposição vise a contribuir para desfazer concepções equivocadas de que estudantes surdos sejam considerados como deficientes da linguagem pelos futuros professores. Esta possibilidade está balizada pela crítica de que o déficit linguístico imposto aos surdos - deve ser compreendido como fruto do processo histórico da humanidade que negou sua formação enquanto cidadão bilíngue, desde [...] o seio familiar até círculos sociais mais amplos, como é o caso da escola, conforme relataram Giroto, Pinho e Martins (2016).

Práxis Educativa, Ponta Grossa, v. 12, n. 3, p. 864-886, set./dez. 2017 Disponível em: <http://www.revistas2.uepg.br/index.php/praxiseducativa $>$ 
Quadro 5 - Recorrência das subcategorias nos planos de ensino da categoria "Conteúdos sobre a Libras"

\begin{tabular}{|c|c|c|c|c|c|}
\hline \multirow{2}{*}{$\begin{array}{c}\text { Instituiç̧ão/Local - } \\
\text { Curso }\end{array}$} & \multirow{2}{*}{ Título/disciplina } & \multirow{2}{*}{ Subcategoria } & \multicolumn{3}{|c|}{ Recorrência } \\
\hline & & & Objetivo & Conteúdo & Ementa \\
\hline $\begin{array}{l}\text { 3.Ufs.Sor - } \\
\text { Matemática }\end{array}$ & Intr. à Libras - Libras I & \multirow{7}{*}{$\begin{array}{l}\text { História da } \\
\text { Libras na } \\
\text { Sociedade }\end{array}$} & $\mathrm{X}$ & & \\
\hline $\begin{array}{l}\text { 3.Ufs. - Educação } \\
\text { Física }\end{array}$ & $\begin{array}{l}\text { Intr. à Língua Brasileira de } \\
\text { sinais }\end{array}$ & & & & $\mathrm{X}$ \\
\hline $\begin{array}{l}\text { 1.UnB - Educação } \\
\text { Física }\end{array}$ & $\begin{array}{l}\text { Intr. ao estudo da língua } \\
\text { brasileira de sinais }\end{array}$ & & & $\mathrm{X}$ & \\
\hline $\begin{array}{l}\text { 3.Ufs.Ar - Ciênc. } \\
\text { Biológicas }\end{array}$ & \multirow{4}{*}{ Libras } & & & & $\mathrm{X}$ \\
\hline 3.Ufs.Ar - Física & & & & & $\mathrm{X}$ \\
\hline 3.Ufs.Sor - Química & & & & & $\mathrm{X}$ \\
\hline $\begin{array}{l}\text { 3.Ufs.Sor - Ciênc. } \\
\text { Biológicas }\end{array}$ & & & $\mathrm{X}$ & & \\
\hline 3.Ufs. - Física & \multirow{5}{*}{ Intr. à Libras - Libras I } & \multirow{22}{*}{ Teoria da Libras } & $\mathrm{X}$ & $\mathrm{X}$ & $\mathrm{X}$ \\
\hline $\begin{array}{l}\text { 3.Ufs.Sor - } \\
\text { Geografia }\end{array}$ & & & $\mathrm{x}$ & $\mathrm{X}$ & $\mathrm{X}$ \\
\hline $\begin{array}{l}\text { 3.Ufs.Sor - } \\
\text { Matemática }\end{array}$ & & & $\mathrm{X}$ & $\mathrm{X}$ & $\mathrm{X}$ \\
\hline $\begin{array}{l}\text { 3.Ufs.Sor - Ciênc. } \\
\text { Biológicas }\end{array}$ & & & $\mathrm{X}$ & $\mathrm{X}$ & $\mathrm{X}$ \\
\hline 3.Ufs. - Filosofia & & & $\mathrm{X}$ & $\mathrm{X}$ & $\mathrm{X}$ \\
\hline $\begin{array}{l}\text { 3.Ufs. - Educação } \\
\text { Física }\end{array}$ & $\begin{array}{l}\text { Intr. à Língua Brasileira de } \\
\text { sinais }\end{array}$ & & $\mathrm{X}$ & $\mathrm{X}$ & $\mathrm{X}$ \\
\hline 1.UnB - Matemática & Intr. ao ensino de Libras & & $\mathrm{X}$ & $\mathrm{X}$ & $\mathrm{X}$ \\
\hline $\begin{array}{l}\text { 1.UnB - Educação } \\
\text { Física }\end{array}$ & \multirow{2}{*}{$\begin{array}{l}\text { Intr. ao estudo da língua } \\
\text { brasileira de sinais }\end{array}$} & & & $\mathrm{X}$ & $\mathrm{X}$ \\
\hline 1.UnB - Pedagogia & & & & $X$ & $\mathrm{X}$ \\
\hline $\begin{array}{l}\text { 3.Ufs.Ar - Ciênc. } \\
\text { Biológicas }\end{array}$ & \multirow{3}{*}{ Libras } & & $\mathrm{X}$ & $\mathrm{X}$ & $\mathrm{X}$ \\
\hline 3.Ufs.Sor - Química & & & $\mathrm{X}$ & $\mathrm{X}$ & $\mathrm{X}$ \\
\hline 3.Ufs.Ar - Física & & & $\mathrm{X}$ & $\mathrm{X}$ & $\mathrm{X}$ \\
\hline 2.Ufs - Geografia & Libras I & & $\mathrm{X}$ & $\mathrm{X}$ & $\mathrm{X}$ \\
\hline 3.Ufs. - Pedagogia & \multirow{2}{*}{ Libras II } & & $\mathrm{X}$ & $\mathrm{X}$ & \\
\hline 3.Ufs. - Filosofia & & & $\mathrm{X}$ & $\mathrm{X}$ & \\
\hline $\begin{array}{l}\text { 2.Ufs - Educação } \\
\text { Física }\end{array}$ & \multirow{6}{*}{ Língua Brasileira de Sinais } & & $\mathrm{X}$ & $\mathrm{X}$ & $\mathrm{X}$ \\
\hline $\begin{array}{l}\text { 2.Ufs - Letras } \\
\text { Estrangeiras }\end{array}$ & & & & $\mathrm{X}$ & $\mathrm{X}$ \\
\hline $\begin{array}{l}\text { 2.Ufs - Ciênc. } \\
\text { Biológicas }\end{array}$ & & & $\mathrm{X}$ & $\mathrm{X}$ & \\
\hline $\begin{array}{l}\text { 2.Ufs - Letras } \\
\text { Alemão }\end{array}$ & & & $\mathrm{X}$ & & $\mathrm{X}$ \\
\hline 2.Ufs - Francês & & & $\mathrm{X}$ & $\mathrm{X}$ & \\
\hline 2.Ufs - Pedagogia & & & $\mathrm{X}$ & $\mathrm{X}$ & $\mathrm{X}$ \\
\hline $\begin{array}{l}\text { 2.Ufs - Educação no } \\
\text { Campo }\end{array}$ & $\begin{array}{l}\text { Língua Brasileira de Sinais } \\
\text { I }\end{array}$ & & & $\mathrm{X}$ & $\mathrm{X}$ \\
\hline 3.Ufs. - Física & \multirow{2}{*}{ Intr. à Libras - Libras I } & \multirow{2}{*}{$\begin{array}{l}\text { Cultura e } \\
\text { Identidade Surda }\end{array}$} & $\mathrm{X}$ & $\mathrm{X}$ & $\mathrm{X}$ \\
\hline 3.Ufs.Sor - & & & $\mathrm{X}$ & $\mathrm{X}$ & $\mathrm{X}$ \\
\hline
\end{tabular}


A disciplina Libras na formação de professores: desafios para a formulação de espaços educacionais...

\begin{tabular}{|c|c|c|c|c|}
\hline Geografia & & & & \\
\hline $\begin{array}{l}\text { 3.Ufs.Sor - } \\
\text { Matemática }\end{array}$ & & $\mathrm{X}$ & $\mathrm{X}$ & $\mathrm{X}$ \\
\hline $\begin{array}{l}\text { 3.Ufs.Sor - Ciênc. } \\
\text { Biológicas }\end{array}$ & & $\mathrm{X}$ & $\mathrm{X}$ & $\mathrm{X}$ \\
\hline 3.Ufs. - Filosofia & & $\mathrm{X}$ & $\mathrm{X}$ & $\mathrm{X}$ \\
\hline 1.UnB - Matemática & Intr. ao ensino de Libras & $\mathrm{X}$ & & $\mathrm{X}$ \\
\hline $\begin{array}{l}\text { 1.UnB - Educação } \\
\text { Física }\end{array}$ & Intr. ao estudo da língua & $\mathrm{X}$ & $\mathrm{X}$ & $\mathrm{X}$ \\
\hline 1.UnB - Pedagogia & & $\mathrm{X}$ & $\mathrm{X}$ & $\mathrm{X}$ \\
\hline $\begin{array}{l}\text { 3.Ufs.Ar - Ciênc. } \\
\text { Biológicas }\end{array}$ & & $\mathrm{X}$ & $\mathrm{X}$ & \\
\hline $\begin{array}{l}\text { 3.Ufs.Sor - Ciênc. } \\
\text { Biológicas }\end{array}$ & Libras & $\mathrm{X}$ & $\mathrm{X}$ & \\
\hline 3.Ufs.Sor - Química & & $\mathrm{X}$ & $\mathrm{X}$ & \\
\hline 3.Ufs.Ar - Física & & $\mathrm{X}$ & $\mathrm{X}$ & \\
\hline 2.Ufs - Geografia & Libras I & $\mathrm{X}$ & $\mathrm{X}$ & $\mathrm{X}$ \\
\hline 3.Ufs. - Pedagogia & I ihe II & & $\mathrm{X}$ & \\
\hline 3.Ufs. - Filosofia & Libras 11 & & $\mathrm{X}$ & \\
\hline $\begin{array}{l}\text { 2.Ufs - Educação } \\
\text { Física }\end{array}$ & & $\mathrm{X}$ & $\mathrm{X}$ & $\mathrm{X}$ \\
\hline $\begin{array}{l}\text { 2.Ufs - Ciênc. } \\
\text { Biológicas }\end{array}$ & Língua Brasileira de Sinais & $\mathrm{X}$ & $\mathrm{X}$ & $\mathrm{X}$ \\
\hline 2.Ufs - Francês & & $\mathrm{X}$ & $\mathrm{X}$ & $\mathrm{X}$ \\
\hline $\begin{array}{l}\text { 2.Ufs - Educação no } \\
\text { Campo }\end{array}$ & $\begin{array}{l}\text { Língua Brasileira de Sinais } \\
\text { I }\end{array}$ & $\mathrm{X}$ & $\mathrm{X}$ & $\mathrm{X}$ \\
\hline
\end{tabular}

Fonte: Elaborada pelas autoras.

A categoria "Conteúdos sobre a Libras", representada no quadro 5, foi dividida em três subcategorias. A primeira subcategoria apresentada foi a História da Libras, que teve 7 disciplinas com recorrência desta abordagem, com predomínio de identificação da subcategoria nas ementas dos planos de ensino (57\%).

Na subcategoria Teoria da Libras, foram encontradas 22 disciplinas e pode-se sugerir, neste caso, que as informações com relação à abordagem da subcategoria estavam descritas tanto nos objetivos, quanto nos conteúdos e nas ementas dos planos (82\%, 95\% e 82\%, respectivamente).

A terceira subcategoria, Cultura e Identidade Surda, foi identificada em 19 disciplinas, com identificação semelhante nos objetivos e conteúdos dos planos de ensino $(89 \%$ e $95 \%$, respectivamente) e de maneira menos expressiva nas ementas desses documentos (68\%). Essas informações nos permitem sugerir que a inserção de disciplinas que abordam a Libras na Educação Superior, apresentam maior preocupação em informar aos futuros docentes aspectos gramaticais, históricos e relacionados à prática discursiva da Libras, ainda que a carga horária para estas disciplinas seja incipiente para dar conta dos temas levantados. 
Quadro 6 - Recorrência das subcategorias nos planos de ensino da categoria "Políticas públicas e fundamentos da educação dos surdos"

\begin{tabular}{|c|c|c|c|c|c|}
\hline \multirow{2}{*}{$\begin{array}{c}\text { Instituição/Local - } \\
\text { Curso }\end{array}$} & \multirow{2}{*}{ Título/disciplina } & \multirow{2}{*}{ Subcategoria } & \multicolumn{3}{|c|}{ Recorrência } \\
\hline & & & Objetivo & Conteúdo & Ementa \\
\hline 3.Ufs. - Física & \multirow{5}{*}{ Intr. à Libras - Libras I } & \multirow{10}{*}{$\begin{array}{l}\text { Educação } \\
\text { Bilíngue }\end{array}$} & & $\mathrm{X}$ & \\
\hline 3.Ufs.Sor - Geografia & & & & $\mathrm{X}$ & \\
\hline $\begin{array}{l}\text { 3.Ufs.Sor - } \\
\text { Matemática }\end{array}$ & & & & $\mathrm{X}$ & \\
\hline $\begin{array}{l}\text { 3.Ufs.Sor - Ciênc. } \\
\text { Biológicas }\end{array}$ & & & & $\mathrm{X}$ & \\
\hline 3.Ufs. - Filosofia & & & & $\mathrm{X}$ & \\
\hline $\begin{array}{l}\text { 3.Ufs. - Educação } \\
\text { Física }\end{array}$ & $\begin{array}{l}\text { Intr. à Língua Brasileira } \\
\text { de sinais }\end{array}$ & & & $\mathrm{X}$ & $\mathrm{X}$ \\
\hline $\begin{array}{l}\text { 3.Ufs.Ar - Ciênc. } \\
\text { Biológicas }\end{array}$ & \multirow{4}{*}{ Libras } & & & $\mathrm{X}$ & \\
\hline $\begin{array}{l}\text { 3.Ufs.Sor - Ciênc. } \\
\text { Biológicas }\end{array}$ & & & & $\mathrm{X}$ & \\
\hline 3.Ufs.Sor - Química & & & & $\mathrm{X}$ & \\
\hline 3.Ufs.Ar - Física & & & & $\mathrm{X}$ & \\
\hline 3.Ufs.Sor - Geografia & \multirow{3}{*}{ Intr. à Libras - Libras I } & \multirow{10}{*}{$\begin{array}{l}\text { Políticas } \\
\text { Públicas } \\
\text { Educacionais e } \\
\text { Linguísticas }\end{array}$} & & $\mathrm{X}$ & \\
\hline $\begin{array}{l}\text { 3.Ufs.Sor - } \\
\text { Matemática }\end{array}$ & & & $\mathrm{X}$ & $\mathrm{X}$ & \\
\hline $\begin{array}{l}\text { 3.Ufs.Sor - Ciênc. } \\
\text { Biológicas }\end{array}$ & & & $\mathrm{X}$ & $\mathrm{X}$ & \\
\hline 1.UnB - Matemática & Intr. ao ensino de Libras & & $\mathrm{X}$ & & $\mathrm{X}$ \\
\hline $\begin{array}{l}\text { 1.UnB - Educação } \\
\text { Física }\end{array}$ & \multirow{2}{*}{$\begin{array}{l}\text { Intr. ao estudo da língua } \\
\text { brasileira de sinais }\end{array}$} & & & $\mathrm{X}$ & \\
\hline $\begin{array}{l}\text { 3.Ufs. - Educação } \\
\text { Física }\end{array}$ & & & & & $\mathrm{X}$ \\
\hline $\begin{array}{l}\text { 3.Ufs.Ar - Ciênc. } \\
\text { Biológicas }\end{array}$ & \multirow{4}{*}{ Libras } & & & & $\mathrm{X}$ \\
\hline $\begin{array}{l}\text { 3.Ufs.Sor - Ciênc. } \\
\text { Biológicas }\end{array}$ & & & & & $\mathrm{X}$ \\
\hline 3.Ufs.Sor - Química & & & & & $\mathrm{X}$ \\
\hline 3.Ufs.Ar - Física & & & & & $\mathrm{X}$ \\
\hline
\end{tabular}

Fonte: Elaborado pelas autoras.

O quadro 6 aponta os resultados referentes à categoria "Políticas públicas e fundamentos da educação de surdos”.

Nesta categoria foi possível identificar duas subcategorias, nomeadas Educação Bilíngue e Políticas Públicas Educacionais e Linguísticas, nas quais foram identificadas 21 disciplinas, 11 e 10 , respectivamente.

Na subcategoria Educação Bilíngue apenas os conteúdos dos planos de ensino apresentaram informações referentes à subcategoria, e somente uma ementa apresentou informações relacionadas à educação bilíngue, além disso, não houve nenhuma observação relevante nos objetivos dos planos de ensino dessas disciplinas.

A subcategoria Políticas Públicas Educacionais e Linguísticas foi observada em 10 disciplinas, e, diferentemente da subcategoria anterior, sua recorrência foi predominante nas ementas dos 
A disciplina Libras na formação de professores: desafios para a formulação de espaços educacionais...

planos de ensino das disciplinas $(60 \%)$. As disciplinas relacionadas nesta subcategoria têm por finalidade destacar as diferentes políticas existentes direcionadas aos surdos, vale mencionar que não se pode inferir qual ênfase é dada nos cursos de graduação, uma vez que há algumas diferenciações quanto à legislação que regulamenta a presença do intérprete na sala de aula, conforme aponta Lodi (2013).

A esse respeito, em outro texto, a mesma autora (LODI, 2014) esclarece as dissonâncias existentes entre a PNEEPEI (BRASIL, 2008) e as recomendações da Lei $n^{\circ}$ 10.436/2002 (BRASIL, 2002) e do Decreto Federal no 5.626/2005 (BRASIL, 2005). Tais medidas, para autora, parecem insuficientes para resolver as questões relativas aos processos educativos de surdos, posto que a implementação destas políticas, tem inviabilizado a busca por uma solução satisfatória em termos de garantia dos direitos linguísticos dos surdos e, evidentemente, da possibilidade de serem escolarizados a partir de uma perspectiva bilíngue. Neste sentido, os conteúdos ministrados nesta categoria parecem indicar um espaço de reflexão importante sobre o tema, aliados à discussões fortuitas da comunidade surda (LODI, 2014) na luta pela conquista da educação bilíngue, assunto recorrente nos dados analisados.

Ainda nessa perspectiva, Machado, Teixeira e Galasso (2017) buscaram contextualizar como se deu a criação do primeiro curso superior online de pedagogia bilíngue e concluem que apesar dos desafios que surgiram, dentre eles: contemplar todos os conteúdos que garantam a formação inicial adequada; otimizar o ambiente virtual de aprendizagem, entre outros, acredita-se que seja um projeto de mudança significativa no campo educacional e que terá muita relevância na área se executado com competência. Por fim, conforme os resultados descritos nos quadros 4, 5 e 6, a disciplina Libras tem figurado nos cursos de formação de professores, no âmbito das licenciaturas, como uma possibilidade de difusão dessa modalidade de linguagem, semelhantemente aos resultados obtidos por Giroto, Martins e Lima (2015).

\section{Considerações finais}

Os aspectos destacados no presente texto figuram, junto a tantos outros aqui não tematizados, como desafios a serem enfrentados pelas IES, no sentido de adequarem suas propostas de formação à realidade educacional atual e às políticas educacionais vigentes (BRASIL, 2008; 2015), principalmente no que diz respeito à educação de surdos na perspectiva bilíngue, seja em escolas bilíngues ou em classes bilíngues em escolas regulares (GIROTO; PINHO; MARTINS, 2016).

Aliados aos agravos relatados, situam a ausência de políticas linguísticas que garantam a legitimidade da luta no reconhecimento da língua de sinais na comunidade surda, o que ocasiona impactos sociais irreparáveis, dentre os quais se destaca o fracasso educacional de uma geração de estudantes surdos, que caminha para a reparação histórica por meio das recentes conquistas legislativas e políticas em favor do respeito à língua dos surdos, ainda que dependam da cobrança permanente e da defesa dos direitos dos surdos, inclusive por meios judiciais.

Acrescenta-se ao fato mencionado que o futuro professor deve garantir aos estudantes surdos o direito à educação, como um bem cultural e inalienável. Assim, a luta em favor da regulamentação da disciplina de Libras na formação docente, constitui-se um espaço importante para desfazer concepções equivocadas que, ainda insistem reproduzir os discursos médicos na qual surdos são tratados como deficientes da linguagem, no processo de escolarização (FERNANDES; MOREIRA, 2009; LODI, 2013). 
Além disso, devido à especificidade de qualificação profissional para atuar nesta disciplina e, principalmente, por amenizar os custos implícitos na reestruturação curricular na formação de professores em atendimento as normativas vigentes que militam em favor da presença de profissionais surdos no exercício desta função e, por conta desta especificidade, tem levado algumas universidades a propor mudanças no título da disciplina - a exemplo de "Libras e Educação Inclusiva"- como observa o documento recentemente divulgado por uma das universidades participante do estudo (UNESP, 2016). Em contrário à posição mencionada, este estudo estima a manutenção do título da disciplina no contexto atual, resguardado pela garantia de estabelecer um espaço de valorização do ensino, da disseminação da Libras e da formulação de práticas docentes formativas - que priorizem a consolidação de propostas educacionais bilíngues, em consonância ao que os surdos querem (BRASIL, 2005; BRASIL, 2014).

Respeitadas as diferenças nos modos de organização institucional da oferta da disciplina nos cursos investigados, o estudo demonstrou que a disciplina Libras tem figurado nos cursos de formação de professores, no âmbito do curso de Pedagogia e demais licenciaturas, como uma possibilidade de difusão dessa modalidade de linguagem, semelhantemente aos resultados obtidos por Giroto, Martins e Lima (2015). De modo geral, sua inserção neste contexto, representa um espaço concreto para os que defendem os direitos linguísticos dos surdos na educação, exigindo que a Libras seja valorizada e disseminada nos espaços de formação docente. Qualquer ação adversa a esse movimento pode representar um retrocesso aos direitos linguísticos dos surdos merecidamente reconhecidos e conquistados.

Medidas desta natureza parecem reforçar a importância de pesquisas que visam a firmar o compromisso das universidades frente aos discursos que priorizam o fortalecimento da luta em favor da consolidação de propostas bilíngues para surdos no contexto educacional brasileiro.

\section{Referências}

BAKHTIN, M. Marximo e filosofia da linguagem. Tradução do russo por Yakobson, R. et al.

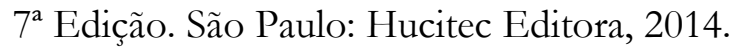

BARDIN, L. Análise de Conteúdo. Edição Revista e Ampliada. São Paulo: Edições 70, 2011.

BRASIL. CAPES - Coordenação de Aperfeiçoamento de Pessoal de Nível Superior. Edital no 49/2012 - Acessibilidade no Ensino Superior, 2012.

BRASIL. Decreto n ${ }^{\circ}$ 5.626, de 22 de Dezembro de 2005. Regulamenta a Lei no 10.436, de 24 de abril de 2002, que dispõe sobre a Língua Brasileira de Sinais e o art. 18 da Lei no 10.098, de 19 de dezembro de 2000. Diário Oficial da União, Brasília, 23 abr. 2005.

BRASIL. Decreto $n^{\circ}$ 7.612, de 17 de Novembro de 2011. Institui o Plano Nacional dos Direitos da Pessoa com Deficiência - Plano Viver sem Limite. Diário Oficial da União, Brasília, 18 nov. 2011.

BRASIL. Lei n ${ }^{\circ}$ 10.436, de 24 de Abril de 2002. Dispõe sobre a Língua Brasileira de Sinais Libras e dá outras providências. Diário Oficial da União, Brasília, 24 abr. 2002. 
A disciplina Libras na formação de professores: desafios para a formulação de espaços educacionais...

BRASIL. Lei $n^{\circ}$ 12.764. Institui a Política Nacional de Proteção dos Direitos da Pessoa com Transtorno do Espectro Autista. Diário Oficial da União, Brasília, 27 dez. 2012.

BRASIL. Lei no 13.146, de 06 de Julho de 2015. Institui a Lei Brasileira de Inclusão da Pessoa com Deficiência (Estatuto da Pessoa com Deficiência). Diário Oficial da União. Brasília, 07 jul. 2015. Disponível em: http://www.planalto.gov.br/ccivil_03/_Ato20152018/2015/Lei/L13146.htm. Acesso em 12 de Maio de 2016.

BRASIL. Ministério da Educação. Conselho Estadual de Educação. Deliberação CEE no 111/2012 de 14 de Março de 2012. Fixa Diretrizes Curriculares Complementares para a Formação de Docentes para a Educação Básica nos Cursos de Graduação de Pedagogia, Normal Superior e Licenciaturas, oferecidos pelos estabelecimentos de ensino superior vinculados ao sistema estadual. Diário Oficial do Estado, São Paulo, 03 fev. 2012.

BRASIL. Ministério da Educação. Conferência Nacional da Educação Básica, 2008.

BRASIL. Ministério da Educação. Conselho Nacional de Educação. Diretrizes curriculares do curso de Pedagogia, de 15 de Maio de 2006, 2006.

BRASIL. Ministério da Educação. Secretaria de Educação Continuada, Alfabetização, Diversidade e Inclusão. Relatório do Grupo de Trabalho designado pelas Portarias $\mathbf{n}^{\mathbf{o}}$ 1.060/2013 e $\mathrm{n}^{\circ}$ 91/2013 para elencar subsídios à Política Linguística de Educação Bilíngue - Língua Brasileira de Sinais e Língua Portuguesa. Brasília: MEC/SEESP, 2014.

BRASIL. Política Nacional de Educação Especial na Perspectiva da Educação Inclusiva, Brasília, 2008. Disponível em: <http://portal.mec.gov.br/seesp/arquivos/pdf/politica.pdf>. Acesso em: 30 de maio de 2016.

COSTA, O. S.; LACERDA, C. B. F. de. A implementação da disciplina de Libras no contexto dos cursos de licenciatura. Revista Ibero-Americana de Estudos em Educação, Araraquara, v. 10, n. esp., p. 759-771, 2015.

FERNANDES, S.; MOREIRA, L. C. Desdobramentos político-pedagógicos do bilinguismo para surdos: reflexões e encaminhamentos. Revista Educação Especial, Santa Maria, v. 22, n. 34, p. 225-236, maio/ago, 2009.

FERNANDES, S.; MOREIRA, L. C. Políticas de educação bilíngue para surdos: o contexto brasileiro. Educar em Revista, Curitiba, v. esp. n. 2, p. 51-69, 2014. DOI: 10.1590/01044060.37014 .

FERNANDES, S. Políticas linguísticas e de identidade(s): a língua como fator de (in)exclusão dos surdos. Revista Trama, Marechal Cândido Rondon, v. 7, n. 14, p. 109-123, jul./dez. 2011.

FERREIRA, S. L. Ingresso, permanência e competência: uma realidade possível para universitários com necessidades educacionais especiais. Revista Brasileira de Educação Especial, Marília, v. 13, n. 1, p. 43-60, jan./abr. 2007. DOI: 10.1590/s1413-65382007000100004 
GIROTO, C. R. M.; MARTINS, S. E. S. de O.; LIMA, J. M. R. de. Formação de professores e inserção da disciplina Libras no Ensino Superior: perspectivas atuais. Revista Ibero-Americana de Estudos em Educação, v. 2, p. 741-758, 2015.

GIROTO, C. R. M.; PINHO, G. G.; MARTINS, S. E. S. de O. A disciplina de Libras na pedagogia: em análise a formação do formador. In: POKER, R. B.; MARTINS, S. E. S. O.; GIROTO, C. R. M. (Orgs.). Educação Inclusiva: em foco a formação de professores. Cultura Acadêmica: São Paulo, 2016, p. 153-172.

LEITE, L. P.; MARTINS, S. E. S. de O. Fundamentos da Educação Inclusiva. São Paulo: Cultura Acadêmica, Marília: Oficina Universitária, 2012.

LODI, A. C. B. Educação bilíngue para surdos e inclusão segundo a Política Nacional de Educação Especial e o Decreto n ${ }^{\circ}$ 5.626/05. Educação e Pesquisa, São Paulo, v. 39, n. 1, p.4963, jan./mar. 2013. DOI: 10.1590/s1517-97022013000100004

LODI, A. C. B. Ensino da língua portuguesa como segunda língua para surdos: impacto na educação básica. In: LACERDA, C. B. F.; SANTOS, L. F. Tenho um aluno surdo, e agora? Introdução à Libras e educação dos surdos. São Carlos: Edfscar, 2014. p. 165-183.

LÜDKE, M.; ANDRÉ, M. Pesquisa em educação: abordagens qualitativas. São Paulo: EPU, 1986.

MACHADO, E. E.; TEIXEIRA, D. E.; GALASSO, B. J. B. Concepção do Primeiro Curso Online de Pedagogia em uma Perspectiva Bilíngue Libras-Português. Revista Brasileira de Educação Especial, Marília, v. 23, n. 1, p. 21-36, jan./mar. 2017. DOI: 10.1590/s141365382317000100003

MAZO, R. Ensino de Arquitetura e concepção de professores sobre acessibilidade, inclusão social, desenvolvimento humano e deficiência. 2010. 168 f. Dissertação (Mestrado em Psicologia), Universidade Estadual Paulista-UNESP, Bauru, SP, 2010.

ROCHA, D.; DEUSDARÁ, B. Análise de Conteúdo e Análise do Discurso: aproximações e afastamentos na (re)construção de uma trajetória. Alea: Estudos Neolatinos, Rio de Janeiro, v. 7, n. 2, p. 305-322, jan./dez. 2005. DOI: 10.1590/s1517-106x2005000200010

UNESCO. Organizações das Nações Unidas para a Educação, Ciência e Cultura, Declaração de Salamanca: Princípios, Políticas e Prática em Educação Especial. Brasília: M. J. CORDE, 1994.

UNESCO. Organizações Das Nações Unidas Para A Educação, Ciência e Cultura. Declaração Mundial sobre Educação Para Todos (Conferência de Jomtien). Tailândia: Unesco, 1990.

UNESP. OFICIO CIRCULAR No. 20/2016. Pró-Reitoria de Graduação da Universidade Estadual Julio de Mesquita Filho, UNESP, 2016. Disponível em: <www.marilia.unesp.br/prograd>. Acesso em: 06 jul. 2016. 
A disciplina Libras na formação de professores: desafios para a formulação de espaços educacionais...

VELDEN, H. F. V.; LEITE, L. P. Método de pesquisa da temática deficiência nos currículos de Psicologia. Psicologia em Estudo, Maringá, v. 18, n. 3, p. 497-507, jul./set. 2013. DOI: $10.1590 /$ s1413-73722013000300011

VITALIANO, C. R. et al. Análises dos currículos dos cursos de pedagogia das universidades públicas dos estados do Paraná e de São Paulo em relação à formação para inclusão de alunos com necessidades educacionais especiais. Revista Eletrônica Pró-docência, Londrina, v. 1, n. 1, p. 1-27, jan./jun. 2012.

Recebido em 12/10/2016

Versão corrigida recebida em 07/06/2017

Aceito em 10/06/2017

Publicado online em 27/07/2017 